\title{
Bazı Tane Sorgum ve Sorgum X Sudanotu Melezi Çeşitlerinde Ekim Zamanının Verim ve Verim Unsurlarına Etkisi Üzerine Bir Araştırma
}

Kemal YILDIRIM

Harran Üniversitesi Fen Bilimleri Enstitüsü

Gülșah BENGISUU

Harran Üniversitesi Ziraat Fakültesi Tarla Bitkileri Bölümü (Sorumlu yazar)

\section{Özet}

$\mathrm{Bu}$ araştırma bazı tane sorgum ve sorgum sudanotu melezi çeşitlerinde ekim zamanının verim ve verim unsurlarına etkisi üzerine Toprak Mahsulleri Ofisi Viranşehir Ajans Müdürlüğü tesisleri uygulama arazisinde yürütülmüştür. Deneme bölünmüş parseller deneme desenine göre 3 tekerrürlü olarak oluşturulmuştur. Araştırmada ana parselleri çeşitler, Kws, Fito, Hay day ve Akdarı alt parselleri ise ekim zamanları 25 Haziran, 5 Temmuz ve 15 Temmuz olarak oluşturulmuştur. 3 farklı zamanda ekimi yapılan sorgumun bölünmüş parseller deneme desenine göre analizler yapılmıştır. Analizlerle: \% 50 çiçeklenme gün sayısı, olgunlaşma gün sayısı, bitki boyu, yaprak sayısı, sap kalınlığı, salkım uzunluğu, salkım ağırlığı, salkım başına tane verimi, salkım başına tane sayısı, salkımda tane oranı, tane verimi, 1000 tane ağırlığı, hektolitre ağırlığı ve ham protein oranı sonuçları incelenmiştir. Bu araştırma sonucunda ele alınan özellikler irdelendiğinde Şanlıurfa ili Viranşehir ilçesi koşullarında sorgum bitkisinin tane verimi bakımından Akdarı ve Hay day çeşitlerinin ilk ekim zamanı, yeşil ot bakımından Fito ve Kws çeşitlerinin ilk ekim zamanı önerilmektedir.

Anahtar Kelimeler: Sorgum, Ekim tarihi, Verim, Çeşit

\section{Some Hybrid Varieties of Again Sorghum and Sorghum Sudanense A Study on The Effect of Sowing Date Yield an Yield Components}

\begin{abstract}
This survey was performed in Land For Practice of Soil Crops Office Agency Management to understand some kinds of sorghum and sorghum x sudanense effects for planting time and crop's elemets. Divided experement parcels were composed, three recurrences for experement pattern. The kind of main parcel were Kws, Fito, Hay day and Akdar1; planting time of down parcels were composed in 25th June, 5th July and 15th July. The Sorghum was planted in three different time and analyzed to divided experement parcels. According to analysis; the results of \%50 number of blooming day, maturation day number, height of plant, number of leaf, stalk thickness, height of bunch, weight of bunch, the aril efficieny to a bunch, numer of
\end{abstract}


aril for a bunch, rate of aril in a bunch, aril efficieny, wight of a thousand arils, weight of hectolitre, and rate of crute protein were found. In conditions of Viranşehir in Şanlıurfa the first planting time for kinds of Akdarı and Hayday are suggested to the crop's effect of Sorghum plant and the first planting for kinds of Fito and Kws to the green plant.

Keywords: Sorghum, Planting date, Crop, Kind

\section{GİRIŞ}

Ülkemizde darı olarak bilinen sorgum türleri gerek kurak alanların değerlendirilmesinde gerekse sulu tarım alanlarında suyun sınırlayıcı olduğu sezonlarda mısır ve diğer kültürü yapılan bitkilere alternatif olması bakımından büyük bir potansiyele sahip bulunmaktadır. Üstelik hem tane hem de yeşil aksamın değişik şekillerde kullanılabilir olması, yem açı̆̆ımızın giderilmesi bakımından bu bitkinin önemini daha da arttırmaktadır. Tanesinden yararlanılan kültür bitkileri içerisinde çok önemli bir yere sahip olan sorgum bitkisinin ülkemizde ziraatının yaygınlaştırılması için gereken önemin verilmesi ve buna yönelik yetiştiricilik ve sslah çalışmaların artırılması gerekmektedir.

$\mathrm{Bu}$ çalışmanın amacı, bazı tane sorgum ve çeşitlerinde ekim zamanının tane veriminin ve verim unsurlarına etkilerinin tespit edilmesidir.

\section{MATERYAL ve METOT}

Araştırma, Toprak Mahsulleri Ofisi Viranşehir Ajans Müdürlüğü tesislerinde bölünmüş parseller deneme desenine göre 3 tekerrürlü olarak kurulmuştur. Araştırmada ana parselleri Batı Akdeniz Tarımsal Araştırma Merkezi Enstitü Müdürlüğünden temin edilen çeşitler (Kws s1, Fito, Hay day ve Akdar1 ) alt parselleri ise ekim zamanları 25 Haziran (E1), 5 Temmuz (E2) ve 15 Temmuz (E3) oluşturulmuştur. Denemenin yürütüldüğü Şanlıurfa ilinin Viranşehir ilçesinde karasal iklimi hüküm sürmektedir. Yazları uzun ve çok sıcak, kışlar çok soğuk geçen yörede yıllık yağış ortalaması $331 \mathrm{~mm}$ ile $473 \mathrm{~mm}$ arasında değişmektedir. Yılın 25 günü sıcaklık $0^{\circ} \mathrm{C}$ 'nin altındadır. En yüksek sıcaklık $+46,5^{\circ} \mathrm{C}$ 'dir. Y1llık sıcaklık fark1 40 derecedir. Bitki örtüsü step’tir (Şanlıurfa Meteoroloji İl Müdürlüğü). Araştırma alanı toprağı tınlı, hafif alkali, fosfor ve potasyum yönünden zengin, Organik madde bakımından fakir, pH'sı nötr, tuzluluk ve kireç oranlarına yetersizdir (Viranşehir İlçe Tarım Müdürlüğü). 
Deneme bölünmüş parseller deneme desenine göre 3 tekerrürlü olarak 2012 y1lı yazlık ürün yetiştirme sezonunda yürütülmüştür. Ekim elle yapılmış olup, ekim sıklığ $70.0 \times 5.0 \mathrm{~cm}$, parsel uzunluğu $3 \mathrm{~m}$ olarak alınmıştır. Deneme 4 sıradan oluşan $8.4 \mathrm{~m}^{2}$ 'lik parsellere yapılmıştır. Ekimle birlikte $6 \mathrm{~kg} / \mathrm{da}$ saf azot (amonyum sülfat formunda), ekimden sonra bitki boyu 30-40 cm'ye ulaştığında $6 \mathrm{~kg} /$ da azot (amonyum nitrat formunda) uygulanmıştır. Sulama bitki boyu müsaade edinceye kadarki dönem yağmurlama daha sonra ise karıklarla sulama işlemi 7 ila 10 gün ara ile yapılmıştır. Çapalama işlemi bitki boyu 30-40 cm'ye ulaştığında yapılmıştır. Çapalama işlemi ile birlikte üst gübre verilmiştir. Hasat, 10.10.2012 tarihinde elle yapılmıştır. Daha sonra salkımlar güneşte bekletilerek kuruduktan sonra harmanlama işlemi yapılmıştır.

Araştırmada, \% 50 çiçeklenme gün sayısı, olgunlaşma gün sayısı, bitki boyu, yaprak sayısı, sap kalınlığı, salkım uzunluğu, salkım ağırlığı, salkım başına tane verimi, salkım başına tane sayısı, salkımda tane oranı, tane verimi, 1000 tane ağırlığı, hektolitre ağırlığı ve ham protein oranı incelenmiştir.

\section{BULGULAR ve TARTIŞMA}

\section{\% 50 Çiçeklenme Gün Sayısı}

\%50 çiçeklenme gün sayısına ait Çizelge 1'de izlenmektedir. Bir parselde toplam bitki sayısının \% 50'sinin salkım gösterdiği tarih ile ekim tarihi arasındaki gün sayısı olarak hesaplanmıştır.

Çizelge 1. Araştırmada incelenen bazı özellikler

\begin{tabular}{|l|l|l|l|l|l|l|}
\hline \multirow{3}{*}{ Çeşitler } & \multicolumn{3}{|c|}{ Ekim Zamanları } & \multicolumn{3}{c|}{ Ekim Zamanları } \\
\cline { 2 - 8 } & \multicolumn{3}{|c|}{ \%50 Çiçeklenme gün sayısı } & \multicolumn{3}{c|}{ Olgunlaşma gün sayısı } \\
\cline { 2 - 8 } & E1 & E2 & E3 & E1 & E2 & E3 \\
\hline Akdarı & 57 & 54 & 49 & 81 & 88 & 94 \\
\hline Kws & 68 & 65 & 61 & 92 & 98 & 107 \\
\hline Fito & 70 & 68 & 64 & 97 & 102 & 109 \\
\hline Hay day & 55 & 53 & 48 & 78 & 83 & 90 \\
\hline
\end{tabular}

Çizelge 1'de izlendiği gibi ilk ekim zamanında en yüksek \% 50 olgunlaşma gün sayısı 70 gün ile Fito çeşidinden, en düşük \% 50 olgunlaşma gün sayısı ise 55 gün ile Hay day çeşidinden alınmıştır. İkinci ekim zamanında ise en yüksek \% 50 olgunlaşma gün sayısı 65 gün ile Fito çeşidinden, en düşük \% 50 olgunlaşma gün sayısı ise 53 gün ile Hay day çeşidinden alınmıştır. Üçüncü ekim zamanında ise en yüksek \% 50 olgunlaşma gün sayısı 64 gün ile Fito çeşidinden, 
en düşük \% 50 olgunlaşma gün sayısı ise 48 gün ile Hay day çeşidinden alınmıştır. Çeşitlerden elde edilen \% 50 çiçeklenme gün sayısına ait değerler Çeçen ve ark. (2005), Sağlamtimur ve ark. (1988), bulgularına kısmen benzer, Desai ve Deore (1980), Ayan (2008) ve Emeklier ve Köksoy (1997)’ ye ait değerlerden düşük bulunmuştur.

\section{Olgunlaşma Gün Sayısı}

Olgunlaşma gün sayısına ait Çizelge 1'de izlenmektedir. Ekimden tanelerin iyice sertleştiğgi ve salkımdan tanenin kolayca ayrıldı̆̆ı döneme kadar geçen gün sayısı olarak hesaplanmıştır. Çizelge 4.2.1'de izlendiği gibi ilk ekim zamanında en yüksek olgunlaşma gün sayısı 97 gün ile Fito çeşidinden, en düşük olgunlaşma gün sayısı ise 78 gün ile Hay day çeşidinden alınmıştır. İkinci ekim zamanında ise en yüksek olgunlaşma gün sayısı 102 gün ile Fito çeşidinden, en düşük olgunlaşma gün sayısı ise 83 gün ile Hay day çeşidinden alınmıştır. Üçüncü ekim zamanında ise en yüksek olgunlaşma gün sayısı 109 gün ile Fito çeşidinden, en düşük olgunlaşma gün sayısı ise 90 gün ile Hay day çeşidinden alınmıştır. Olgunlaşma gün sayısına ait elde ettiğimiz değerler, Ayan (2008) ve Dogget (1988)' e ait değerlerle uyumlu bulunmuştur.

Çizelge 2. Araştırmada incelenen bazı morfolojik özellikler

\begin{tabular}{|c|c|c|c|c|c|c|c|c|c|c|c|c|}
\hline \multirow{3}{*}{ Çeşitler } & \multicolumn{4}{|c|}{ Ekim Zamanları } & \multicolumn{4}{|c|}{ Ekim Zamanları } & \multicolumn{4}{|c|}{ Ekim Zamanları } \\
\hline & \multicolumn{4}{|c|}{ Bitki boyu } & \multicolumn{4}{|c|}{ Yaprak sayıs1 } & \multicolumn{4}{|c|}{ Sap Kalınlığı } \\
\hline & E1 & $\mathrm{E} 2$ & E3 & Ortalama & E1 & $\mathrm{E} 2$ & E3 & Ortalama & E1 & E2 & E3 & Ortalama \\
\hline Akdarı & $327,7 \mathrm{a}$ & $315,7 \mathrm{a}$ & $302,6 \mathrm{a}$ & $315,3 \mathrm{a}$ & 95,7 & 88,9 & 83,8 & $89,4 \mathrm{a}$ & $2,90 \mathrm{a}$ & $2,02 \mathrm{a}$ & $2,01 \mathrm{a}$ & $2,31 \mathrm{a}$ \\
\hline Kws & $328,1 \mathrm{a}$ & $317,7 \mathrm{a}$ & $292,7 b$ & $312,8 \mathrm{a}$ & 82,1 & 80,2 & 76,2 & $79,5 b$ & $1,94 \mathrm{~b}$ & $1,96 \mathrm{a}$ & $2,22 \mathrm{a}$ & $2,04 \mathrm{~b}$ \\
\hline Fito & $271,9 \mathrm{~b}$ & $271,4 \mathrm{~b}$ & $260,6 \mathrm{c}$ & $267,9 \mathrm{~b}$ & 48,8 & 51,3 & 51,8 & $56,7 \mathrm{c}$ & $1,04 \mathrm{~b}$ & $1,08 \mathrm{~b}$ & $1,07 \mathrm{~b}$ & 1,06 \\
\hline Hay day & $260,6 \mathrm{c}$ & $255,0 \mathrm{c}$ & $240,8 \mathrm{~d}$ & $252,1 \mathrm{c}$ & 58,4 & 60 & 41,3 & $47,1 \mathrm{~d}$ & $1,02 b$ & $1,07 \mathrm{~b}$ & $1,02 b$ & 1,04 \\
\hline Ortalama & $297,1 \mathrm{a}$ & $289,9 \mathrm{~b}$ & $274,1 \mathrm{c}$ & & $71,3 \mathrm{a}$ & $70,1 \mathrm{a}$ & $63,3 \mathrm{~b}$ & & $1,72 b$ & $1,53 \mathrm{a}$ & $1,58 \mathrm{~b}$ & \\
\hline \multirow{3}{*}{ LSD } & çeşit & \multicolumn{3}{|c|}{4,62} & \multicolumn{4}{|c|}{3,27} & \multicolumn{4}{|c|}{1,9} \\
\hline & ekim zamanı & \multicolumn{3}{|c|}{3,98} & \multicolumn{4}{|c|}{2,83} & \multicolumn{4}{|c|}{1,02} \\
\hline & interaksiyon & \multicolumn{3}{|c|}{3,53} & & & & & \multicolumn{4}{|c|}{3,63} \\
\hline
\end{tabular}

\section{Bitki Boyu (cm)}

Bitki boyuna ait Çizelge 2'de izlenmektedir. Her bir parselde 10 adet bitkinin toprak yüzeyinden salkım ucuna kadar olan uzunlukları ölçülmüş ve ortalaması bulunmuştur. Çizelge 2'de izlendiği gibi ilk ekim zamanında en yüksek bitki boyu $328.1 \mathrm{~cm}$ ile Kws çeşidinden, en düşük bitki boyu ise $260.6 \mathrm{~cm}$ ile Hay day çeşidinden alınmıştır. İkinci ekim zamanında ise en yüksek bitki boyu $317.7 \mathrm{~cm}$ ile Kws çeşidinden, en düşük bitki boyu ise $255 \mathrm{~cm}$ ile Hay day Year 3/ 2019 , Volume-3, Issue-1 | https://ispecjournal.com 
çeşidinden alınmıştır. Üçüncü ekim zamanında ise en yüksek bitki boyu $302.6 \mathrm{~cm}$ ile Fito çeşidinden, en düşük bitki boyu ise $240.8 \mathrm{~cm}$ ile Hay day çeşidinden alınmıştır. Çeşitlerden elde edilen bitki boyuna ait değerler. Gül ve Başbağ (1999), (148-249 cm), Yılmaz ve Hosaflığlu (2000), (114-249 cm), Baytekin ve Tansı (1990), (236.78-271.37 cm)'nın bulgularıyla uyumlu, Sağlamtimur (1988), (183.87- $355.37 \mathrm{~cm})$, bulgularına kısmen benzer, Özbilen (1991), (231.19 cm), İptaş (1993), (198.2 cm) ve Seydoşoğlu ve Saruhan (2017) bulgularından yüksek bulunmuştur.

\section{Yaprak Sayısı (adet/bitki)}

Yaprak sayısına ait Çizelge 2'de izlenmektedir. Her bir parselde 10 bitkide yaprak sayıs1 sayılmış ve ortalaması bulunmuştur. Çizelge 2'de görüldüğg̈ gibi ekim döneminde çeşit interaksiyonu önemsiz olduğu, ekim zamanı x çeşit zamanı interaksiyonu önemli olduğu saptanmıştır. Çizelge 2'de görüldüğü gibi ilk ekim zamanında en yüksek yaprak sayısı 95.7 adet ile Fito çeşidinden, en düşük yaprak sayısı ise 48.8 adet ile Akdarı çeşidinden alınmıştır. İkinci ekim zamanında ise en yüksek yaprak sayısı 88.9 adet ile Fito çeşidinden, en düşük yaprak sayısı 51.3 adet ile Akdarı çeşidinden alınmıştır. Üçüncü ekim zamanında ise en yüksek yaprak sayısı 83.8 adet ile Fito çeşidinden, en düşük yaprak sayısı ise 41.3 adet ile Hay day çeşidinden alınmıştır. Çeşitlerden elde edilen yaprak sayısına ait değerler, Yüksel (2006), Acar ve ark (2002), Emeklier ve Köksoy (1997)’ye ait değerlerden yüksek bulunmuştur.

\section{Sap Kalınlı̆̆ı (cm)}

Sap kalınlığına ait olarak Çizelge 2'de görülmektedir. Her bir parselde 10 bitkide sap çapları kumpas yardımı ile ölçülmüş ve ortalaması bulunmuştur. Çizelge 2'de görüldüğü gibi ilk ekim zamanında en yüksek sap kalınlığı $2.9 \mathrm{~cm}$ ile Fito çeşidinden, en düşük sap kalınlığı ise 1.02 cm ile Hay day çeşidinden alınmıştır. İkinci ekim zamanında ise en yüksek sap kalınlığı 2.02 cm ile Fito çeşidinden, en düşük sap kalınlığı ise $1.07 \mathrm{~cm}$ ile Hay day çeşidinden alınmıştır. Üçüncü ekim zamanında ise en yüksek sap kalınlığg $2.22 \mathrm{~cm}$ ile Kws çeşidinden, en düşük sap kalınlığ 1 ise $1.02 \mathrm{~cm}$ ile Hay day çeşidinden alınmıştır.

\section{Salkım A Ăırlı̆̆ı (g)}

Salkım ağırlığına ait Çizelge 3'te görülmektedir. Her bir parselde 10 adet salkım ayrı ayrı tartılmış ve ortalaması bulunmuştur. Çizelgede de görüldüğü gibi ilk ekim zamanında en yüksek salkım ağırlığı $65.4 \mathrm{~g}$ ile Fito çeşidinden, en düşük salkım ağırlığı ise $58.6 \mathrm{~g}$ ile Akdarı Year 3/2019, Volume-3, Issue-1 | https://ispecjournal.com 
çeşidinden alınmıştır. İkinci ekim zamanında ise en yüksek salkım ağırlığı $55.3 \mathrm{~g}$ ile Akdarı çeşidinden, en düşük salkım ağırlığı ise 50.5 g ile Hay day çeşidinden alınmıştır. Üçüncü ekim zamanında ise en yüksek salkım ağırlığg 50.8 g ile Kws çeşidinden, en düşük salkım ağırlığı ise 44.6 g ile Hay day çeşidinden alınmıştır. Salkım ağırlığına ait elde ettiğimiz değerler, Ayan (2008) ve Karadaş (2011)'e ait değerlerden düşük bulunmuştur.

\section{Salkım Başına Tane Verimi (g/bitki)}

Salkım başına tane verimine ait Çizelge 3'te görülmektedir. Salkımlar ayrı ayrı harmanlanarak taneleri ayrılmış ve tartılarak ortalaması bulunmuştur. Çizelge 3'te görüldüğü gibi ilk ekim zamanında en yüksek salkım başına tane verimi 58.2 g ile Akdarı çeşidinden, en düşük salkım başına tane verimi ise $46.4 \mathrm{~g}$ ile Kws çeşidinden alınmıştır. İkinci ekim zamanında ise en yüksek salkım başına tane verimi 46.8 g ile Hay day çeşidinden, en düşük salkım başına tane verimi ise 40.6 ile Kws çeşidinden alınmıştır. Üçüncü ekim zamanında ise en yüksek salkım başına tane verimi 41.7 g Hay day çeşidinden, en düşük salkım başına tane verimi ise 36.1 ile Kws çeşidinden alınmıştır.

Çizelge 3. Araştırma incelenen bazı özellikler

\begin{tabular}{|c|c|c|c|c|c|c|c|c|c|c|c|c|}
\hline \multirow{3}{*}{ Çeşitler } & \multicolumn{4}{|c|}{ Ekim Zamanları } & \multicolumn{4}{|c|}{ Ekim Zamanları } & \multicolumn{4}{|c|}{ Ekim Zamanlar1 } \\
\hline & \multicolumn{4}{|c|}{ Salkım ağırlı̆̆ 1} & \multicolumn{4}{|c|}{ Salkım başına tane verimi } & \multicolumn{4}{|c|}{ Salkım başına tane sayısı } \\
\hline & E1 & E2 & E3 & Ortalama & E1 & E2 & E3 & Ortalama & E1 & E2 & E3 & Ortalama \\
\hline Akdarı & 65,4 & 54,2 & 50,2 & 56,6 & 50,3 & 44 & 38,9 & 44,5 & $978 \mathrm{a}$ & $942 \mathrm{a}$ & $896 \mathrm{a}$ & $938 \mathrm{a}$ \\
\hline Kws & 61,9 & 54,5 & 50,8 & 55,8 & 46,4 & 40,6 & 36,1 & 41 & $781 \mathrm{~b}$ & $718 \mathrm{~b}$ & $651 \mathrm{~b}$ & $716 \mathrm{~b}$ \\
\hline Fito & 58,6 & 55,3 & 47,6 & 52,8 & 58,2 & 45,8 & 40,2 & 48,1 & $793 b$ & $744 \mathrm{~b}$ & $693 b$ & $743 b$ \\
\hline Hay day & 60,4 & 50,5 & 44,6 & 52,9 & 49,9 & 46,8 & 417 & 6,1 & $1024 \mathrm{a}$ & $965 \mathrm{a}$ & $862 a$ & $950 \mathrm{a}$ \\
\hline Ortalama & $61,6 \mathrm{a}$ & $53,6 b$ & 48,3 & & $51, \mathrm{a}$ & $44,3 \mathrm{~b}$ & 39,2 & & $894 a$ & $842 \mathrm{ab}$ & $775 b$ & \\
\hline \multirow{3}{*}{ LSD } & çeşit & \multicolumn{3}{|c|}{4,64} & & & & & \multicolumn{4}{|c|}{6,23} \\
\hline & ekim zamanı & \multicolumn{3}{|c|}{4,01} & \multicolumn{4}{|c|}{5,12} & \multicolumn{4}{|c|}{14,48} \\
\hline & interaksiyon & & & & & & & & \multicolumn{4}{|c|}{10,24} \\
\hline
\end{tabular}

\section{Salkım Başına Tane Sayısı (adet/salkım)}

Salkım başına tane sayısına ait Çizelge 3'te görülmektedir. Salkım başına tane verimi o parselden elde edilen 1000 tane ağırlığına bölünerek elde edilmiştir. Çizelge 3'te görüldüğü gibi ilk ekim zamanında en yüksek salkım başına tane sayısı 1024 adet ile Hay day çeşidinden, en düşük salkım başına tane verimi ise 781 adet ile Kws çeşidinden alınmıştır. İkinci ekim 
zamanında ise en yüksek salkım başına tane sayısı 965 adet ile Hay day çeşidinden, en düşük salkım başına tane sayısı ise 718 adet ile Kws çeşidinden alınmıştır. Üçüncü ekim zamanında ise en yüksek salkım başına tane sayısı 896 adet ile Akdarı çeşidinden, en düşük salkım başına tane sayısı 651 adet ile Kws çeşidinden alınmıştır. Salkım başına tane sayısına ait elde ettiğimiz değerler, Emeklier ve Köksoy (1997)’ye ait değerlerden düşük bulunmuştur.

\section{Salkımda Tane Oranı (\%)}

Salkım da tane oranına ait Çizelge 4'te görülmektedir. Hasat edilen salkımlar tartılmıştır, harmanlandıktan sonra elde edilen tane ağırlığı salkım ağırlığına oranlanarak hesaplanmıştır. Çizelge 4.10.2' de görüldüğü gibi ekim dönemlerinde çeşit interaksiyonu önemsiz olduğu, ekim zamanı x çeşit interaksiyonu önemli olduğu saptanmıştır. Çizelge 4'dt görüldüğü gibi ilk ekim zamanında en yüksek salkımda tane oranı \% 92.8 ile Akdarı çeşidinden, en düşük salkımda tane oranı ise \% 79.6 ile Fito çeşidinden alınmıştır. İkinci ekim zamanında ise en yüksek salkımda tane oranı \% 90.7 ile Akdarı çeşidinden, en düşük salkımda tane oranı \% 72.6 ile Kws çeşidinden alınmıştır. Üçüncü ekim zamanında ise en yüksek salkımda tane oranı \% 86.2 ile Akdarı çeşidinden, en düşük salkımda tane oranı \% 70.6 ile Fito çeşidinden alınmıştır. Salkımda tane oranına ait elde ettiğimiz değerler, Gül ve Başbuğ (2005), Yeşildağ (2005), Oral (2001), Yılmaz ve Hosaflıŏlu (2000), Emeklier ve Köksoy (1997), Kızılşimşek ve Paksoy (2003) ve Keskin ve ark. (2005)'e ait değerlerden yüksek bulunmuştur.

Çizelge 4. Denemede incelenen bazı özellikler

\begin{tabular}{|c|c|c|c|c|c|c|c|c|c|c|c|c|}
\hline \multirow{3}{*}{ Çeşitler } & \multicolumn{4}{|c|}{ Ekim Zamanları } & \multicolumn{4}{|c|}{ Ekim Zamanları } & \multicolumn{4}{|c|}{ Ekim Zamanları } \\
\hline & \multicolumn{4}{|c|}{ Salkımda tane oranı } & \multicolumn{4}{|c|}{ Tane verimi } & \multicolumn{4}{|c|}{ Ham protein oranı } \\
\hline & E1 & E2 & E3 & Ortalama & E1 & E2 & E3 & Ortalama & E1 & $\mathrm{E} 2$ & E3 & Ortalama \\
\hline Akdarı & 79,6 & 75,2 & 70,6 & $75,1 \mathrm{~b}$ & $496 \mathrm{a}$ & $468 \mathrm{a}$ & $420 \mathrm{a}$ & $461 \mathrm{a}$ & $16,8 \mathrm{a}$ & $16,2 \mathrm{a}$ & $15,28 \mathrm{a}$ & $16,1 \mathrm{a}$ \\
\hline Kws & 81 & 72,6 & 73,2 & $75,6 \mathrm{~b}$ & $372 b$ & $330 \mathrm{~b}$ & $278 \mathrm{~b}$ & $326 \mathrm{~b}$ & $16,52 \mathrm{a}$ & $15,87 \mathrm{a}$ & $15,61 \mathrm{a}$ & $16 \mathrm{a}$ \\
\hline Fito & 92,8 & 90,7 & 86,2 & $89,9 \mathrm{a}$ & $354 \mathrm{~b}$ & $318 \mathrm{~b}$ & $246 \mathrm{~b}$ & $306 \mathrm{~b}$ & $15,24 \mathrm{~b}$ & $15,18 \mathrm{~b}$ & $14,24 \mathrm{~b}$ & $14,48 \mathrm{~b}$ \\
\hline Hay day & 91,9 & 90,5 & 84,3 & $88,9 \mathrm{a}$ & $483 \mathrm{a}$ & $461 \mathrm{a}$ & $432 \mathrm{a}$ & $458 \mathrm{a}$ & $15,76 \mathrm{~b}$ & $14,98 \mathrm{~b}$ & $14,13 \mathrm{~b}$ & $14,95 \mathrm{~b}$ \\
\hline Ortalama & $86,3 \mathrm{a}$ & $82,2 \mathrm{~b}$ & $78,6 \mathrm{c}$ & & $426 \mathrm{a}$ & $394 a b$ & $34 \mathrm{ab}$ & & $16 \mathrm{ab}$ & $15,54 \mathrm{ab}$ & $14,81 b$ & \\
\hline \multirow{3}{*}{ LSD } & çeşit & \multicolumn{3}{|c|}{2,48} & \multicolumn{4}{|c|}{485} & \multicolumn{4}{|c|}{2,34} \\
\hline & ekim zamanı & \multicolumn{3}{|c|}{2,15} & \multicolumn{4}{|c|}{4,24} & \multicolumn{4}{|c|}{4,38} \\
\hline & interaksiyon & & & & \multicolumn{4}{|c|}{0,72} & \multicolumn{4}{|c|}{2,82} \\
\hline
\end{tabular}

\section{Tane Verimi (kg/da)}


Tane verimlerine ait Çizelge 4'te görülmektedir. Parselden hasat edilen salkımlar harmanlandiktan sonra elde edilen parsel verimleri dekara çevrilerek bulunmuştur. Çizelgede de görüldüğü gibi ilk ekim zamanında en yüksek tane verimi 496 kg ile Akdarı çeşidinden, en düşük tane verimi ise $354 \mathrm{~kg}$ ile Fito çeşidinden alınmıştır. İkinci ekim zamanında ise en yüksek tane verimi $468 \mathrm{~kg}$ ile Akdarı çeşidinden, en düşük tane verimi ise $318 \mathrm{~kg}$ ile Fito çeşidinden alınmıştır. Üçüncü ekim zamanında ise en yüksek tane verimi $432 \mathrm{~kg}$ ile Hay day çeşidinden, en düşük tane verimi ise $246 \mathrm{~kg}$ Fito çeşidinden alınmıştır. Çeşitlerden elde edilen tane verimine ait değerler, Elçi (1999), Magallenes (1993), Sağlamtimur ve ark (1988), ve Sağlamtimur ve ark. (1986)'nın değerlerine kısmen benzerdir. Siefers ve Bolsen (1997)' e ait değerden yüksek bulunmuştur.

\section{Ham Protein Oranı (\%)}

Ham protein oranına ait (\%) Çizelge 4'te görülmektedir. Her bir parselde bir miktar tane ögütülerek ve numuneler Kjeldhal yöntemine göre analiz edilerek azot oranları 6.25 ile çarpılmak suretiyle ham protein oranları bulunmuştur. Çizelgede de görüldüğü gibi ekim dönemlerinin ham protein oranına ait interaksiyonu önemli bulunmuştur. Çizelge 4'te görüldüğü gibi ilk ekim zamanında en yüksek ham protein oranı \% 16.8 ile Fito çeşidinden, en düşük ham protein oranı ise \% 15.24 ile Akdarı çeşidinden alınmıştır. İkinci ekim zamanında en yüksek ham protein oranı \% 16.2 ile Fito çeşidinden, en düşük ham protein oranı ise \% 14.98 Hay day çeşidinden alınmıştır. Üçüncü ekim zamanında ise en yüksek ham protein oranı \% 15.61 ile Kws çeşidinden, en düşük ham protein oranı ise \% 14.13 ile Hay day çeşidinden alınmıştır. Çeşitlerden elde edilen ham protein oranlarına ait değerler, Aydın ve Tokluoğlu (1986), Yılmaz ve Hosaflığlu (2000)'ne ait değerlerden yüksek bulunmuştur.

\section{SONUÇLAR VE ÖNERILER}

Araştırmada ele alınan özellikler birlikte değerlendirildiğinde, Şanlıurfa ili Viranşehir ilçesi koşullarında sorgum bitkisinin tane verimi bakımından Akdarı ve Hay day çeşitlerinin ilk ekim zamanı, yine yeşil ot bakımından Fito ve Kws çeşitlerinin ilk ekim zamanı önerilmektedir.

\section{AÇIKLAMA}

Bu çalışma, ilk yazarın (Kemal YILDIRIM) yüksek lisans tezinden üretilmiştir. Ayrıca, bu çalışmanın özeti, “EJONS VI INTERNATIONAL CONGRESS ON MATHEMATICS - 
ENGINEERING -NATURAL \& MEDICAL SCIENCES” kongresinde sunulmuş olup, kongrenin özet kitabında basılmıştır.

\section{KAYNAKLAR}

ACAR, R., AKBUDAK, A. ve SADE, B., 2002. Konya Ekolojik Şartlarında Silajlık SorgumSudan Otu Melezlerin Verimleri ile Verimi Etkileyen bazı Özelliklerin Belirlenmesi. S.Ü Ziraat Fakültesi.

AYAN, İ., 2008. Konya Koşullarında Ekim zamanı Denemesi üzerine çalışma, Selçuk Üniversitesi Ziraat Fakültesi Dergisi, 22(35):8-5 2008 Konya

BAYTEKİN, H. ve TANSI, V., 1990. Yem bitkileri Yetiştirme, Çukurova Üniversitesi Ziraat Fakültesi Ders Kitabı No:74 TAB-206, Çukurova Üniversitesi Ziraat Fakültesi Ofset ve Teksir Atölyesi, Adana, 238s.

ÇEÇEN, S. ve ark., 2005. Batı Akdeniz Sahil Kuşağında Sorgum, Sudan Otu ve Mısırın II. Ürün Olarak Değerlendirilmesi Batı Akdeniz Tarımsal Araştırma Enstitüsü, Akdeniz Üniversitesi Ziraat Fakültesi Dergisi, 18(3),337-341.

DESAİ. ve DEORE., 1980. Comparison of two Sorghum Genotypes for Sugar and Fiber Production, Industrial Crops and Products, 7, p: 265-272.

EMEKLİER. ve KÖKSOY., 1997. Tarım Bilimleri Dergisi 1997, 3 (3) 20 Ankara

GÜL, İ. ve BAŞBAĞ, M., 1999. Diyarbakır Sulu Koşullarında İkinci Ürün Olarak Sorgum, Sorgum x Sudan Otu Melezi ve Sudan Otu Çeşitlerinde Verim ve Verim Çeşitlerinin İncelenmesi. Türkiye 3. Tarla Bitkileri Kongresi. Cilt III Çayır-Mera Yem Bitkileri ve Yemeklik Tane Baklagiller, Adana.

ELÇİ, Ş., 1999. Yem Bitkileri Kültürü ve Önemi. Çayır mera Amenajmanı ve Islahı (Mera Kanunu Eğitim ve Uygulama El Kitabı -1-). TC. Tar. Köy İşl. Bak., Çayır Mera Yem Bit.ve Havza Gel dai. Bşk.7-19 Ankara.

İPTAŞ, S., 1993. Tokat Yöresinde Sorgum Bitkisinden Yararlanma İmkanları Tarla Bitkileri Kongresi cilt:3, İzmir.

KARADAŞ, S., 2011. Farklı Ekim Sıklıklarında İkinci Ürün Olarak Ekilen Sorgum x Sudan Otu Melezlerinin Verim ve Bazı Verim Unsurlarının Belirlenmesi, Selçuk Üniversitesi Fen Bilimleri Enstitüsü Tarla Bitkileri Ana Bilim Dalı Konya-2011. KESKİN, B., YILMAZ, İ.H. ve AKDENIZ, H., 2005. Van Koşullarında Sorgum x Sudan Otu Melezi Çeşitlerinde Hasat Zamanının Verim ve Verim Unsurlarına Etkisi. Atatürk Üniversitesi Ziraat Fakültesi Dergisi 36 (2), 145-150, 2005. Erzurum.

KIZILŞIMIŞEK, M. ve PAKSOY, T., 2003. Kahramanmaraş Koşullarında Farklı Ekim Sıklığının Sudanotu Bitkinsin (Sorgum Sudananse (Piper) Stapf) Bazı Tarımsal Özellikleri ile 
Ilık Kullanımı Ve Yaprak Alanı Gelişimi Üzerine Etkisi; Türkiye 5. Tarla Bitkileri Kongresi 13-17- Ekim 2003 Sf. 453-457. Diyarbakır.

ORAL .K., 2001. Yüzüncü Y1l Üniversitesi Ziraat Fakültesi Dergisi Sayı 4-3 2001 Van.

SAĞLAMTIMUR., TÜKEL, TANSI, ANLARSAL. ve HATİOĞLU., 1986. Çukurova

Koşullarında Yem Bitkileri Adaptasyon Denemeleri, Ç.Ü.Z.F. Dergisi, 1(3): 37-51.

SAĞLAMTIMMUR, T. ve BAYTEKİN, H., 1988. Çukurova Koşullarında İkinci Ürün Olarak

Yetiştirilebilecek Silaj Sorgum Çeşitlerinin Bazı Tarımsal Karakterlerinin Saptanması Üzerine

Bir Araştırma, Ç.Ü.Z.F. Dergisi3(3): 40.

SAĞLAMTIMUR, T., OKANT, M., TANSI, V. ve BAYTEKİN H., 1989. Güney Doğu Anadolu Bölgesi Sulu Koşullarda II. Ürün Olarak Yetiştirilen Üç Sorgum Çeşidinde Ekim Zamanının Verim ve Bazı Tarımsal Karakterlere Etkisi Üzerine bir Araştırma. Çukurova Üni. Ziraat Fak. Dergisi cilt:4, Sayı:2. Adana.

SEYDOŞOĞLU, S., SARUHAN, V. 2017. Farklı Ekim Zamanlarının Bazı Silajlık Mısır Çeşitlerinde Verim ve Verim Unsurlarına Etkisinin Belirlenmesi (Doktora Tezi). Ege Üniversitesi Ziraat Fakültesi Dergisi, 54(4):377-383.

SİEFERS, M. K. and BOLSEN K. K., 1997. Agronomic and Silage Quality Traits Of Forage Sorghum Süleyman Demirel Üniversitesi Fen Bilimleri Enstitüsü Dergisi, 9-3 (2005),x-x. Isparta.

YEŞİLDAĞ, K., 2005. Van Koşullarında Ekim Zamanının Bazı Silajlık SorgumxSudanotu (Sorghum bicolor (1.) Moench-Sorghum sudanense Stapf.) Melez Çeşitlerinde Verim ve Verim Unsurlarına Etkileri, Yüzüncü Yıl Üniv. Fen Bil. Enst. (Basılmamış Yüksek Lisans Tezi), Van, 41s.

YILMAZ, İ. ve HOSAFLIOĞLU., 2000. Van Koşullarında Uygun Silajlık Sorgum, Sudanotu ve Sorgum x Sudanotu Melezi Çeşitlerinin Belirlenmesi Üzerine Bir Araştırma İnternational Animal Nutrition Congress, 2000. Isparta. YÜKSEL, O., 2006. Sorgum ve Sudanotu Melezlerinde Verim ve Verim Unsurlarına Kalite Özelliklerinin Belirlenmesi Üzerine Araştırma 2006, Isparta. 